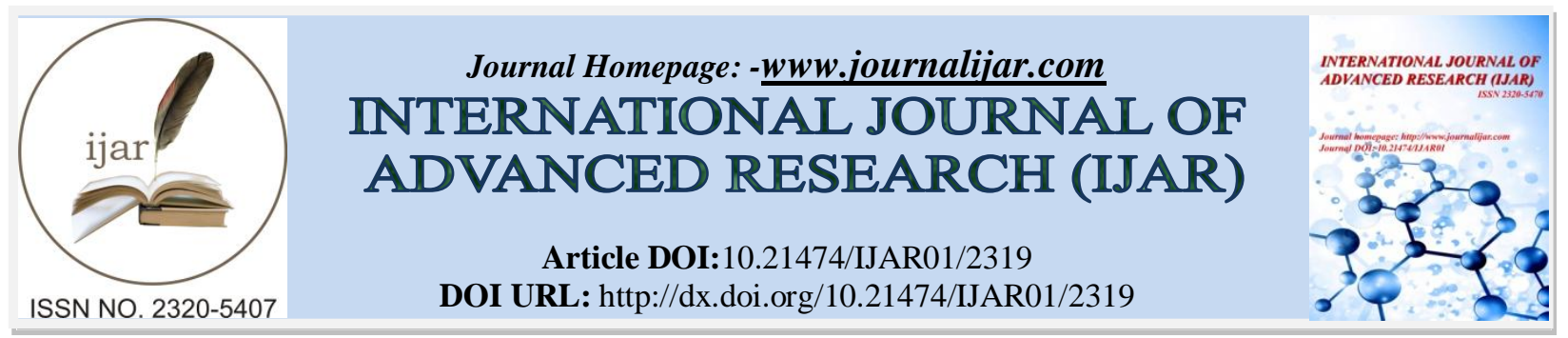

RESEARCH ARTICLE

\title{
THE CONTRIBUTION OF TECHNOLOGY ON INDONESIAN ECONOMY: NATIONAL, SECTORAL AND SPATIAL PERSPECTIVES.
}

\author{
Muchdie $^{1}$, Prihawantoro S. ${ }^{2}$, Alkadri $^{3}$ and Sugema ${ }^{4}$. \\ 1. Department of Management, Post Graduate School, UHAMKA. \\ 2. Centre for Technopreneurship and Industrial Cluster, BPPT. \\ 3. Technology Centre for Specific Region, BPPT. \\ 4. Department of Information Technology, Faculty of Engineering, UHAMKA.
}

\section{Manuscript Info}

(........................

Manuscript History

Received: 29 September 2016

Final Accepted: 30 October 2016

Published: November 2016

Key words:-

Technology contribution; Indonesian economy; national; sectoral, spatial.

\section{Abstract}

This paper reports a research that aimed to analysis the contribution of technology on Indonesian economy at national, sectoral and spatial perspectives. Growth accounting decomposition technique was employed to calculate the contribution of factors production in the economy. The results showed that, on average, technology contribution to Indonesian economy, in term of TFP growth, was too small $(8.79 \%)$ if compared to the TFP growth of other countries, especially in the developed countries. Even if compared with the contribution of other factors contribution, such as capital (74.1\%) and labor $(17.1 \%)$. Sectorally, the contribution of technology on Indonesian economy varied among sector. The highest and gave positive contribution were Other Services (72.6\%) and Manufacturing (52.6\%). The lowest and gave negative contribution were Agriculture $(-55.1 \%)$ and Financial, Rental and Corporate Services (-38.7\%). Spatially, the contribution of technology on Indonesian economy also varied. The highest and gave positive contribution were the Island of Java (47.9\%) and Bali-Nusa Tenggara Island (30.4\%). The lowest and gave negative contributions were Maluku-Papua Islands (-95.4\%) and Kalimantan Island (-24.7\%)

Copy Right, IJAR, 2016,. All rights reserved.

\section{Introduction}

Indonesia is one of the largest economies in Southeast Asia and is one of the emerging market economies of the world. The country is also a member of G-20 major economies and classified as a newly industrialized country. It is the sixteenth largest economy in the world by nominal GDP and is the eighth largest in terms of GDP (PPP). Indonesia still depends on domestic market, and government budget spending and its ownership of state-owned enterprises and the administration of prices of a range of basic goods including, rice, and electricity plays a significant role in Indonesia market economy, but since the 1990s, 80 percent of the economy has been controlled by private Indonesians and foreign companies. In the aftermath of the financial and economic crisis that began in mid1997 the government took custody of a significant portion of private sector assets through acquisition of nonperforming bank loans and corporate assets through the debt restructuring process and the companies in custody has been sold out by privatization several years later. Since 1999 the economy has recovered and growth has 
accelerated to over 4-6\% in recent years; Indonesian economy grows on average at 5.06 per cent per year at period between 1967- 2011 (Prihawantoro, et al, 2013).

Economic growth is the increase in the inflation-adjusted market value of the goods and services produced by an economy over time. It is conventionally measured as the percent rate of increase in real gross domestic product, or real GDP, usually in per capita terms. Growth is usually calculated in real terms to eliminate the distorting effect of inflation on the price of goods produced. Measurement of economic growth uses national income accounting (Bjork, G, J., 1999).

Economic growth has traditionally been attributed to the accumulation of human and physical capital and the increase in productivity arising from technological innovation (Lucas, R. E. 1988). Before industrialization technological progress resulted in an increase in the population, which was kept in check by food supply and other resources, which acted to limit per capita income, a condition known as the Malthusian trap (Galor, O, 2005; Clark, G., 2007). The rapid economic growth that occurred during the Industrial Revolution was remarkable because it was in excess of population growth, providing an escape from the Malthusian trap (Clark, G., 2007). Countries that industrialized eventually saw their population growth slow-down, a phenomenon known as the demographic transition.Most of the economic growth in the 20th century was due to increased output per unit of labor, materials, energy, and land (less input per widget). The balance of the growth in output has come from using more inputs. Both of these changes increase output. The increased output included more of the same goods produced previously and new goods and services (Kendrick, J. W. 1961). During the Industrial Revolution, mechanization began to replace hand methods in manufacturing, and new processes streamlined production of chemicals, iron, steel, and other products (Landes, D, S.,1969). Machine tools made the economical production of metal parts possible, so that parts could be interchangeable (Hounshell, D, A., 1984)

In Ricardian economics, the theory of production and the theory of growth are based on the theory or law of variable proportions, whereby increasing either of the factors of production (labor or capital), while holding the other constant and assuming no technological change, will increase output, but at a diminishing rate that eventually will approach zero. These concepts have their origins in Thomas Malthus's theorizing about agriculture. Malthus's examples included the number of seeds harvested relative to the number of seeds planted (capital) on a plot of land and the size of the harvest from a plot of land versus the number of workers employed (Bjork, G, J, 1999). Solow, R, M., (1956) and Swan, T. W., (1956) developed what eventually became the main model used in growth economics in the 1950s. This model assumes that there are diminishing returns to capital and labor. Capital accumulates through investment, but its level or stock continually decreases due to depreciation. Due to the diminishing returns to capital, with increases in capital/worker and absent technological progress, economic output/worker eventually reaches a point where capital per worker and economic output/worker remains constant because annual investment in capital equals annual depreciation. The Solow-Swan model is considered an exogenous growth model because it does not explain why countries invest different shares of GDP in capital nor why technology improves over time. Instead the rate of investment and the rate of technological progress are exogenous. The value of the model is that it predicts the pattern of economic growth once these two rates are specified. Its failure to explain the determinants of these rates is one of its limitations.

Unsatisfied with the assumption of exogenous technological progress in the Solow-Swan model, economists worked to endogenize technology in the 1980s. They developed the endogenous growth theory that includes a mathematical explanation of technological advancement (Lucas, 1988). This model also incorporated a new concept of human capital, the skills and knowledge that make workers productive. Unlike physical capital, human capital has increasing rates of return. Research done in this area has focused on what increases human capital, for instanceeducation or technological change, for exampleinnovation (Helpman, E., 2004). Three sources of economic growth were capital accumulation growth, labour growth and technological progress.

Solow's (1957) paper was a landmark in the development of growth accounting. It was not the first paper to make an explicit decomposition of the sources of growth into contributions from factor inputs and from output per unit of total input. This had been done several times since the pioneering paper by Fabricant (1954), and with more detail, by Abramovitz (1956), and Kendrick (1961).But it was Solow (1957) that put the growth economics into growth accounting making clear its interpretation in terms of the distinction between shifts of and moves along the aggregate production function. Another major development in the practice of growth accounting was the publication of Jorgenson and Griliches (1967). These authors made revisions to the crude measure of TFP that reduced it from 
1.6 to 0.1 per cent per year for the United States during 1945-1965. They focused on the measurement of capital services and produced a much more sophisticated index of capital input growth while also correcting labour quality for changes in education in a conceptually similar way to Denison (1962).

Previousresearch on technology contribution, using growth accounting method that have been published, among others, by Carre et al., (1975) on France, Ohkawa and Rosovsky (1972) on Japan, and Matthews et al. (1982) for the UK together with a succession of papers from the study of the United States culminating in Abramovitz and David (2001). As further useable historical national income accounts have become available, the country coverage of longrun historical growth accounting has expanded and papers in this tradition continue to be published. In recent years, these have included Schulze (2007) on Austria-Hungary, Lains (2003) on Portugal, and Prados de la Escosura and Roses (2007) on Spain.

Employing growth accounting method, the objective of this paper is to analysis on the contribution of technology on Indonesian economy at national, sectoral and spatialperspectives.

\section{Method of Analysis:-}

The method for calculating TFP, as a measure of technology contribution, in this research was growth accounting method. This method has been used in many countries to calculate TFP. So the results can easily be compared with other countries.Using the production function of Cobb-Douglass, as:

$$
Q_{t}=A_{t} F\left(K_{t} L_{t}\right)
$$

where $Q_{t}$ is output in year-t, $K_{t}$ is Capital and $L_{t}$ is Labor. Hananto Sigit (2004) calculated TFP with formulating trans-log production function as:

$$
\begin{aligned}
& \ln Q_{t}=\ln \alpha_{0}+\alpha_{t} T+\alpha_{k} \ln K_{t}+\alpha_{l} \ln L_{t}+1 / 2 \beta_{k k}\left(\ln K_{t}\right)^{2}+\beta_{k l} \ln K_{t} \ln L_{t} \\
& +1 / 2 \beta_{l l}\left(\ln L_{t}\right)^{2}+\beta_{k T} T \ln K_{t}+\beta_{T l} T \ln L_{t}+1 / 2 \beta_{T T} T^{2}
\end{aligned}
$$

If equation (2), differentiated toward time, then :

$$
\begin{aligned}
Q_{t}^{*}= & \alpha_{t}+\alpha_{k} K_{t}^{*}+\alpha_{l} L_{t}^{*}+\beta_{k k}\left(\ln K_{t}\right) K_{t}^{*}+\beta_{l k}\left(K_{t}^{*} \ln L_{t}+L_{t} * \ln K_{t}\right) \\
& +\beta_{l l}\left(\ln L_{t}\right) L_{t}^{*}+\beta_{k T}\left(T K_{t}^{*}+\ln K_{t}\right)+\beta_{l T}\left(T L_{t}^{*}+\ln L_{t}\right)+\beta_{T T} T
\end{aligned}
$$

Equation (3)is a growth equation. Start notasion, *, indicate a continum growth. Equation (3) can be rewritten as

$$
Q_{t}^{*}=T F P_{t}^{*}+S_{k} K_{t}^{*}+S_{l} L_{t}^{*}
$$

Based on equation (4), the value of TFP can be calculated. As the equation (4) is a continum equation, but the values needed are discrit TFP then the equation of TFP growth reformulated as:

$$
\begin{aligned}
T_{F P G} & =1 / 2\left(T F P_{t}^{*}+T F P_{t-1}{ }^{*}\right) \\
& =\left(\ln Q_{t}-\ln Q_{t-1}\right)-1 / 2\left(S_{k t}+S_{k t-1}\right)\left(\ln K_{t}-\ln K_{t-1}\right) \\
& -1 / 2\left(S_{l t}+S_{l t-1}\right)\left(\ln L_{t}-\ln L_{t-1}\right)
\end{aligned}
$$

With the equation (5), the TFP growth at year can easily be calculated.

Data needed for this study were: 1. Gross Domestic Product and/or Gross Regional Domestic Product, 2. Capital Stock, 3. Labour, 4. Wage/Salary, and 5. Depreciation. Data adjusted by excluding indirect tax, so data of GDP and or GRDP are data at factors cost. For national analysis data are available for the year of 1967-2011, for sectoral analysis data are available for the year of 1977-2007 and for spatial analysis data are available for year 202-2010.

After data adjustment process, steps in calculation TFP growth using growth accounting methodare as follows:

1. Calculate labor income share year-t $\left(\mathrm{LIS}_{\mathrm{t}}\right)$ with formula :

$$
\text { LIS }_{t}=\frac{\text { Wage/Salary at year }-t}{\text { GDP year } t} \text { (6) }
$$

2. Calculate average labor income share at year-t $\left(L I S A_{t}\right)$ :

$L I S A_{t}=1 / 2\left(L I S_{t}+L I S_{t-1}\right)$

where:

LIS $\quad=$ Labor income share at year-t

$L I S_{t-1} \quad=$ Laborincome share at year $\mathrm{t}-1$

3. Calculate capital income share at year-t $\left(\mathrm{KIS}_{\mathrm{t}}\right)$ with formula:

KIS $_{t} \quad=1-$ LIS $_{t}$ 
4. Calculate average capital income shareat year- $\mathrm{t}\left(\mathrm{KISA}_{\mathrm{t}}\right)$ :

$K I S A_{t}=1 / 2\left(K I S_{t}+K I S_{t-1}\right)$

where:

$K I S_{t} \quad=$ Capital income share year-t

$K I S_{t-1} \quad=$ Capital income shareyear $\mathrm{t}-1$

5. Calculate the rate of economic growth at year-t $\left(E G_{t}\right)$ :

$E G_{t}=\left(\ln G D P_{t}-\ln G D_{t-1}\right) \times 100$

$G D P_{t}=$ GDP at constant price at year-t

$G D P_{t-1}=\mathrm{GDP}$ at constant price at year $\mathrm{t}-1$

For sectoral calculation:

$S G i_{t}=\left(\ln V A i_{t}-\ln V A i_{t-1}\right) \times 100$

where:

$V A i_{t} \quad=$ Value-Added sector $\mathrm{i}$ at constant price at year- $\mathrm{t}$

$V A i_{t-1}=$ Value-Added sector $\mathrm{i}$ at constant price at year $\mathrm{t}-1$

6. Calculate the rate of capital stock growth at year $-\mathrm{t}\left(\mathrm{KG}_{\mathrm{t}}\right)$ :

$K G_{t} \quad=\left(\ln K_{t}-\ln K_{t-1}\right) \times 100$

where :

$K_{t} \quad=$ Capitak stock at year-t

$K_{t-1}=$ Capital stock at yeat- $\mathrm{t}-1$

7. Calculate weigthed average the growth rate of capital stock at year-t $\left(\mathrm{KGA}_{\mathrm{t}}\right)$ :

$K G A_{t}=1 / 2\left(K I S_{t}+K I S_{t-1}\right) \times\left(\ln K_{t}-\ln K_{t-1}\right) \times 100$

8. Calculate the growth rate of labor at year-t $\left(\mathrm{LG}_{\mathrm{t}}\right)$ :

$L G_{t} \quad=\left(\ln L_{t}-\ln L_{t-1}\right) \times 100$

where:

$L_{t} \quad=$ Labor at year-t

$L_{t-1} \quad=$ Labor at year- $\mathrm{t}-1$

9. Calculate weigthed average of the labor growth at year-t $\left(\mathrm{LGA}_{\mathrm{t}}\right)$ :

$L G A_{t} \quad=1 / 2\left(L I S_{t}+L I S_{t-1}\right) x\left(\ln L_{t}-\ln L_{t-1}\right) \times 100$

10. The growth rate of TFP at year-t $\left(\mathrm{TFPG}_{\mathrm{t}}\right)$ can be calculated as follow:

$T F P G_{t}=E G_{t}-K G A_{t}-L G A_{t}$

Further more, contribution of factors such as labor, capital and TFP on economic growth are calculated as:
11. Contribution of capital
$=\frac{\text { Equation (12) }}{\text { Equation (10) }} \times 100$
$=\frac{\text { Equation (14) }}{\text { Equation (10) }} \times 100$
12. Contribution of labor
$=\frac{\text { Equation (15) }}{\text { Equation (10) }} \times 100$

\section{Results and Discussion:-}

Table 1: presents the contribution of factors production in Indonesian economy at national level. On average Indonesian economy grows at 5.06 per cent per year for period 1976 to 2011. The highest economic growth happened at oil-boom phase (7.62\%) that occurred between 1976-1981. Negative growth happened at multi-crisis phase $(-1.03 \%)$ that occurred between 1997-2001. Technology contribution, indicated by TFP, nationally was only 08.79 per cent. It was too small compared to the contribution of technology on American economy (26\% average from 1799-1979), and at private bussiness reached 52 per cent in raverage at period 1948-1996 as well as other advanced countries (Hulten, 2000). In Austria, Schulze (2007) found that technology contribution was 14.4 per cent in period of 1870-1890 and 30.5 per cent in 1891-1910. Broadberry (1998) reported that technology contribution to German economy was 32.3 per cent for the period of 1871-1991 and 33.5 per cent in period of 1892-1911. Craft (1995) and Mattews et al (1982) reported that contribution of technology on Great Britain economiy was, on average for period 1700-1913, 33.9 per cent. In Italy Rossi et al (1992) reported that TFP growth was 32.2 per cent for period of 1920-1973. As Kranzt and Schon (2007) reported, the contribution of technology on Sweeden economy was 22.3 per cent in the period of 1850-1973. This small percentage of technology contribution on Indonesian economy were also confirmed by other studies. For instance, Aswicahyono et.al. (1996) found that the TFP growth in the manufacturing sector was only positive for the periods 1976-1981, 1982-1985, and 1986-1991, findings which 
were also confirmed by Abimanyu (1995) and Osada (1994). It is also too small compared to contribution of labour (17.1\%) and capital (74.1\%). In recession phase, the contribution of technology on Indonesian economy was, even, negative $(-95.36 \%)$. The highest contributuion of technology in Indonesian economy occurred in multi-crisis phase (74.32\%) because of negative economic growth, followed by economic revitalization phase (26.3\%) and oil-boom phase $(8.45 \%)$.

Table 1:Contribution of Factors Production on Indonesian Economy, National Dimension, 1967-2011.

\begin{tabular}{lccccc}
\hline \multicolumn{1}{c}{ Phase } & Year & PDB Growth & \multicolumn{3}{c}{ Contribution to PDB Growth (\%) } \\
\cline { 5 - 6 } & & & Capital & Labour & TFP \\
\hline Oil Boom & $1976-1981$ & $7.62(100 \%)$ & 72,46 & 19,09 & 8,45 \\
Recession & $1982-1986$ & $4.24(100 \%)$ & 161.42 & 33.94 & $-95,36$ \\
Deregulation & $1987-1996$ & $6.67(100 \%)$ & 72.15 & 17.05 & 10.80 \\
Multi-crisis & $1997-2001$ & $-1.03(100 \%)$ & 21.86 & 3.82 & 74.32 \\
\hline Economic Revitalization & $2002-2011$ & $5.38(100 \%)$ & 59.62 & 14.08 & 26.30 \\
\hline Indonesia & $1976-2011$ & $5.06(100 \%)$ & 74.13 & 17.07 & 8.79 \\
\hline
\end{tabular}

Source : Prihawantoro, S., et al (2013).

Table 2: Contribution of Factors Production on Indonesian Economy, Sectoral Dimension, 1977-2007.

\begin{tabular}{lcccc}
\hline \multicolumn{1}{c}{ Sector } & $\begin{array}{c}\text { PDB } \\
\text { Growth }\end{array}$ & \multicolumn{2}{c}{ Contribution to PDB Growth (\%) } \\
\cline { 5 - 5 } & & Capital & Labour & TFP \\
\hline Agriculture & $3,14(100 \%)$ & $4,51(143.6 \%)$ & $0,36(11.5 \%)$ & $-1,73(-55.1 \%)$ \\
Mining and Quarrying & $1,48(100 \%)$ & $-0,17(-11.5 \%)$ & $1,51(102.0 \%)$ & $0,14(9.5 \%)$ \\
\hline Manufacturing & $8,26(100 \%)$ & $2,57(31.1 \%)$ & $1,35(16.3 \%)$ & $4,34(52.6 \%)$ \\
\hline Electricity, Gas and Drinking Water & $9,87(100 \%)$ & $7,09(71.8 \%)$ & $3,08(31.2 \%)$ & $-0,30(-3.0 \%)$ \\
\hline Construction & $6,30(100 \%)$ & $-0,21(-3.3 \%)$ & $6,21(98.7 \%)$ & $0,29(4.6 \%)$ \\
\hline Trade, Hotel and Restaurant & $4,94(100 \%)$ & $5,29(107.1 \%)$ & $0,95(19.2 \%)$ & $-1,30(-26.3 \%)$ \\
\hline Transportation and Communication & $7,77(100 \%)$ & $3,63(46.7 \%)$ & $1,85(23.8 \%)$ & $2,29(29.5 \%)$ \\
\hline Financial, Rental and Corporate Services & $7,02(100 \%)$ & $6,22(88.6 \%)$ & $3,52(50.1 \%)$ & $-2,71(-38.7 \%)$ \\
\hline Other Services & $3,98(100 \%)$ & $-1,57(-39.4 \%)$ & $2,66(66.7 \%)$ & $2,89(72.6 \%)$ \\
\hline Indonesia & $5.08(100)$ & $2.79(74.13)$ & $0.73(17.07)$ & $1.56(8.79)$ \\
\hline
\end{tabular}

Source:Prihawantoro, S., et al (2009).

Sectorally, the contribution of technology on Indonesian economy for period of 1977-2007 is presented in Table 2. The highest contribution was occurred at Other Services (72.6\%), followed by Manufacturing (52.6\%) and Transportation and Communication (29.5\%). Negative contribution occurred in Agriculture (-55.1\%), followed by Financial, Rental and Corporate Service (-38.7\%), Trade, Hotel and Restaurant (-26.3\%) and Electricity, Gas and Drinking Water (-3.0\%).In terms of the TFP by industry, Timmer (1999) estimated that TFP performance varied greatly across industries. During the period 1975-1981, TFP growth rates ranged from very high (12\%) in the wood industry to low (-5\%) for chemicals. In 1982-1985, the basic metals industry performed best (14\%), while TFP in nonmetallic minerals slumped (-8\%). The log export ban seems to have had an adverse impact on efficiency in the 
wood industry, with TFP growth becoming negative (-2\%). The period 1986-90 showed annual TFP growth rates of over 5 per cent for all industries except chemicals. Furthermore, between 1991 and 1995, TFP levels appeared to be rising very rapidly particularly for food, beverages, tobacco and the metal product and machinery industries, while there was a marked slump in the basic metal industry. Therefore, all industries - except chemicals and non-metallic minerals - experienced a TFP growth of at least 2 per cent between 1975 and 1995. The low level of TFP growth in the area of non-metallic minerals (especially cement manufacturing) was perhaps due to government regulations aimed at improving efficiency levels in this industry.

Table 3:Contribution of Factors Production on Indonesian Economy, Regional Dimension, 2002-2010.

\begin{tabular}{lcccc}
\hline \multicolumn{1}{c}{ Region/Island } & \multirow{2}{*}{$\begin{array}{c}\text { PDB } \\
\text { Growth }\end{array}$} & \multicolumn{3}{c}{ Contribution to PDB Growth (\%) } \\
\cline { 5 - 5 } & & Capital & Labour & TFP \\
\cline { 5 - 5 } & $4.57(100)$ & $2.88(63.0)$ & $0.88(19.3)$ & $0.81(17.7)$ \\
Sumatera & $5.42(100)$ & $2.30(42.5)$ & $0.52(9.6)$ & $2.60(47.9)$ \\
\hline Java & $3.65(100)$ & $3.92(107.3)$ & $0.64(17.4)$ & $-0.90(-24.7)$ \\
\hline Kalimantan & $6.41(100)$ & $3.69(57.5)$ & $1.11(17.4)$ & $1.61(25.1)$ \\
\hline Sulawesi & $5.01(100)$ & $2.51(50.2)$ & $0.97(19.4)$ & $1.73(30.4)$ \\
\hline Bali-Nusa Tenggara & $3.42(100)$ & $4.65(135.9)$ & $2.03(59.5)$ & $-3.26(-95.4)$ \\
\hline Maluku-Papua & $5.08(100)$ & $2.79(74.13)$ & $0.73(17.07)$ & $1.56(8.79)$ \\
\hline Indonesia & & &
\end{tabular}

Source: Prihawantoro, S., et al., (2013).

Table 3: provides results at regional perspective, based on 6 big Island aggregations. Technology contribution on Indonesian economy was $8.79 \%$. Technology contribution varies among Island; there were positive contribution and negative contributions. There were two Islands in which the contributions of technology were negative, namely in Kalimantan $(-0.24 .7 \%)$ and in Maluku-Papua (-95.4\%). Island with positive technological contributions were Sumatera (17.7\%), Java (47.9\%), Sulawesi (25.1\%) and Bali-Nusa Tenggara (30.4\%). Java Island had the highest of percentage in technology contribution on Indonesia economy. It is followed by Bali-Nusa Tenggara (30.4\%), Sulawesi $(25.1 \%)$ and Sumatera (17.7\%). But, on average, the contribution of technology in Indonesian economy still very small.

\section{Conclusion:-}

From the results and discussion, it could be concluded that, firstly, the contribution of technology on Indonesian economy $(8.79 \%)$ was relatively small compared to the contribution of technology on developed countries. It also small compared to the contribution other factors of production, such as capital (74.13\%) and labor (17.7\%). Secondly, the contribution of technology on Indonesian economy sectorally varied from negative to positive. Negative contribution was given by Agriculture (-55.1\%), Financial, Rental and Corporate Service (-38.7\%), Trade, Hotel and Restaurant (-26.3\%) and Electricity, Gas and Drinking Water (-3.0\%). Positive contribution was given by Other Services (72.6\%), Manufacturing (52.6\%), Transportation and Communication (29.5\%), Mining and Quarrying (9.5\%) and Construction (4.6\%). Thirdly, spatially the contribution of technology on Indonesian economy also varied among Islands. Maluku-Papua Island give negative contribution (-95.4\%) as well as Kalimantan Island (24.7\%). Other Island that contributes positively was Java Island (47.9\%), Bali-Nusa Tenggara Island (30.4\%), Sulawesi Island (25.1\%) and Sumatera Island (17.7\%). 


\section{References:-}

1. Abimanyu, A., (1995); The Indonesian Economy and Total factor Productivity, Singapore Economic Review, Vol 40, no. 1, pp.: 25-40.

2. Abramovitz, M. and David, P, A., (1973); Reinterpreting Economic Growth: Parables and Realities. American Economic Review Papers and Proceedings Vol 63, pp.: 428-39.

3. Abramovitz, M.,(1956); Resource and Output Trends in the United States since 1870, American Economic Review Papers and Proceedings. Vol 46. pp.: 5-23.

4. Albers, R., and Groote, P.,(1996); The Empirics of Growth. De Economist Vol 144, pp.: 429-44.

5. Aswicahyono, H., Bird, K., and Hal, H., (1996); What Happens to Industrial Structure When Countries Liberalise? Indonesia since the Mid-1980s, Journal of Development Studies Vol 32 No 3, pp.: 340-63.

6. Bjork, G, J., (1999). The Way It Worked and Why It Won't: Structural Change and the Slowdown of U.S. Economic Growth. Westport, CT; London: Praeger. pp.: 2, 67. ISBN: 07596532-5.

7. Broadberry, S.N.,(1998); How Did the United States and Germany Overtake Britain? A Sectoral Analysis of Comparative Productivity Levels. Journal of Economic History Vol 58, pp.: 375-407.

8. Carre, J-J., Dubois, P., and Malinvaud, E., (1975); French Economic Growth. Stanford:Stanford University Press.

9. Clark, G., (2007); A Farewell to Alms: A Brief Economic History of the World, Princeton: Princeton University Press. ISBN: 978-0-691-12135-2.

10. Crafts, N.,(1995); Exogenous or Endogenous Growth? The Industrial Revolution Reconsidered. Journal of Economic History Vol 55, pp.: 745-772.

11. Denison, E. F.,(1962); the Sources of Economic Growth in the United States and the Alternatives before Us. New York: Committee for Economic Development.

12. Fabricant, S.,(1954); Economic Progress and Economic Change. In NBER 34th Annual Report. New York.

13. Galor, O., (2005); From Stagnation to Growth: Unified Growth Theory. Handbook of Economic Growth, Elsevier. pp.: 171-293.

14. Hananto, S., (2004);Total Factor Productivity Growth: Survey Report, Part II National Report on Indonesia, Tokyo: APO

15. Helpman, E., (2004); The Mystery of Economic Growth. Harvard University Press.

16. Hounshell, D, A., (1984), From the American System to Mass Production, 1800-1932: The Development of Manufacturing Technology in the United States, Baltimore, Maryland: Johns Hopkins University Press, ISBN: 978-0-8018-2975-8, LCCN: 8301626

17. Hulten, C. R., (2000), Total Factor Productivity: A Short Biography, Working Paper 7471, CambridgeMassachusset: National Bureau of Economic Research.

18. Jorgenson, D. W., and Griliches, Z.,(1967); The Explanation of Productivity Change. Review of Economic Studies 34: 249-83.

19. Kendrick, J. W, (1961); Productivity trends in the United States, Princeton: Princeton University Press.

20. Krantz, O. and Schon, (2007); Swedish Historical National Accounts, 1800-2000. Lund:Almqvist and Wiksell International.

21. Lains, P., (2003); Catching Up to the European Core: Portuguese Economic Growth, 1910-1990. Explorations in Economic History Vol 40, pp.: 369-86.

22. Lucas, R. E.,(1988); On the mechanics of economic development, Journal of monetary economics, Vol 22, No.1, pp. 3-42

23. Matthews, R. C. O., Feinstein, C. H, and J. C., Odling-Smee, J.C, (1982); British Economic Growth 18561973. Stanford: Stanford University Press.

24. Ohkawa, K. and Rosovsky, H., (1972); Japanese Economic Growth: Trend Acceleration in the Twentieth Century, Stanford: Stanford University Press.

25. Osada, H., (1994); Trade Liberalization and FDI Incentives in Indonesia: The Impact on Industrial Productivity, The Developing Economies, Vol. 32, No. 4, pp.: 479-491.

26. Prados de la Escosura, L. and Roses, J., (2007); The Sources of Long-Run Growth in Spain, 1850-2000. Centre for Economic Policy Research Discussion Paper No.6189.

27. Prihawantoro, S., Alkadri, Mien Askinatin, Andi Tabrani, Supomo and Abdul Azis Wasil, (2009).Peranan Teknologi Dalam Pertumbuhan Ekonomi Indonesia, (The Role of Technology in Indonesian Economic Growth), Pusat Pengkajian Kebijakan Inovasi Teknologi (Centre for Innovation Technology Policy), Jakarta: Badan Pengkajian dan Penerapan Teknologi (The Agency for the Assessment and Application of Technology).

28. Prihawantoro, S., Irawan Suryawijaya, Ramos Hutapea, Ugay Sugarmansyah, Alkadri, Wawan Rusiawan, dan Muhammad Yorga Permana (2013). Peranan Teknologi Dalam Pertumbuhan Ekonomi Koridor-Koridor 
Ekonomi Indonesia: Pendekatan Total Factor Productivity. Pusat Pengkajian Kebijakan Inovasi Teknologi (Centre for Innovation Technology Policy). Badan Pengkajian dan Penerapan Teknologi (The Agency for the Assessment and Application of Technology). Jakarta.

29. Rossi, N., Sorgato, A., and Toniolo, G.,(1992); Italian Historical Statistics, 1890-1990. Working Paper No. 18, University of Venice Dipartimento di Scienze Economiche.

30. Schulze, M. S., (2007). Origins of Catch-Up Failure: Comparative Productivity Growth in the Habsburg Empire, 1879-1910. European Review of Economic History 11: 189-218.

31. Solow, R. M., (1956); A Contribution to the Theory of Economic Growth, Quarterly Journal of Economics, 70(1), p pp. 65-94.

32. Solow, R. M.,(1957); Technical Change and the Aggregate Production Function. Review of Economics and Statistics Vol. 39, pp.: 312-20.

33. Swan, T, W., (1956); Economic Growth and Capital Accumulation. Economic Record, Vol 32, pp.: 334-61. doi:10.1111/j.1475-4932.1956.tb00434.x.

34. Timmer, M.P., (1999); Indonesia Ascent on the technology Ladder: Capital Stock and Total Factor Productivity in Indonesian Manufacturing, 1975-1995, Bulletin of Indonesian Economic Studies, Volume 35. No. 1, pp: 7597. 